\title{
Deskripsi Keterampilan Dasar Mengajar Mahasiswa Calon Guru Setelah Menerapkan Metode Inkuiri Terbimbing Pada Materi IPA Dan Matematika
}

\author{
Muh. Ajwar ${ }^{1)}$, Fifi Faridah $^{1)}$, Mariamah $^{1)^{*}}$ \\ ${ }^{1)}$ STKIP Taman Siswa Bima \\ ${ }^{*}$ mariamahmariamah85@yahoo.co.id
}

Abstrak: Mahasiswa sebagai calon guru sangat diperlukan untuk dibekali dengan kemampuan mengajar yang baik, sehingga nanti setelah lulus dan menjadi guru dapat melaksanakan pembelajaran yang kreatif dan inovatif. Kenyataan dilapangan bahwa mahasiswa calon guru masih belum menguasai berbagai keterampilan dasar mengajar. Tujuan peneltian ini untuk mengembangakn keterampilan dasar mengajar mahasiswa calon guru melalui penerapan metode inkuiri terbimbing. Jenis penelitian ini adalan penelitian deskriptif, nantinya akan mendeskripsikan kemampuan mahasiswa dalam mengajar dengan materi yang ambil berkaitan dengan matematika dan IPA. Subjek penelitian adalah mahasiswa prodi PGSD semester VI yang sedang mengampu mata kuliah PPL I. Adapun hasil penelitian bahwa nilai rata-rata kemampuan mahasiswa dalam menyusun RPP sebesar 70,7 sedangakn reinforcemen dengan rata-rata sebesar 69 , kamampaun bertanya dengan rata-rata 71 , rata-rata untuk kemampuan menutup pelajaran sebesar 72,7 dan rata-rata kemampuan menutup sebesar 74

Kata Kunci: Keterampilan Dasar Mengajar, Mahasiswa Calon Guru, Metode Inkuiri Terbimbing

\section{Pendahuluan}

Pembelajaran yang berkulitas ditandai oleh pencapaian tujuan yang telah ditetapkan dengan maksimal. Kualitas pembelajaran sangat bergantung dari berbagai faktor, salah satu faktor penting adalah faktor guru sebagai orang yang terlibat langsung dalam proses pembelajaran sehari-hari. Guru yang profesional tentu bisa melaksanakan pembelajaran dengan baik. Tidak bisa dipungkiri bahwa masih ada ditemukan berbagai permasalahan yang berkaitan dengan kemampuan mengajar guru. Menurut (Muhamad Ajwar et al., 2019) menyampaikan bahwa mahasiswa sebagai calon guru masih banyak ditemukan kurang terampil dalam melakukan praktek mengajar. Hasil penelitian (Widodo et al., 2017) dan hasil penelitian (Abu, 2014) bahwa guru dalam menutup pelajaran tidak melakukan kegiatan merangkum materi yang baru dipelajari, selain itu pada saat membuka pelajaran kurang mengaitkan materi (apersepsi). Masalah lain yang ditemukan dari hasil penelitian Guera dan Widyastuti (Khakiim et al., 2016) bahwa guru kurang mampu mengatur waktu, pengelolaan kelas belum baik serta kurang mampu dalam menutup pelajaran karena waktu yang kurang terkontrol, guru dalam mengajar kurang mampu melaksanakan ketermapilan menutup pelajaran.

Masalah-masalah di atas tidak jauh berbeda dengan masalah yang ditemukan dalam penelitian ini bahwa mahasiswa calon guru masih ditemukan kurang menguasai keterampilan dasar mengajar, informasi ini diperoleh dari hasil wawancara dengan guru pendamping pada saat mahasiswa melaksanakan prakte lapangan di sekolah. Untuk mengatasi masalah tersebut dilakukan berbagai upaya untuk membekali mahasiswa dengan berbagai keterampilan dasar mengajar. Menurut (Mariamah, n.d.) bahwa guru atau dosen perlu untuk melaksanakan pembelajaran yang menyengkan dan memotivasi siswa. Dalam penelitian ini, solusi yang di ambil adalah dengan menerapkan metode ingkuiri terbimbing dalam mata kuliah micro teaching. Metode inkuiri terbimbing (guidedinquiry), adalah metode pembelajaran yang menuntut mahasiswa untuk menemukan sendiri konsep melalui petunjuk-petunjuk seperlunya dari seorang dosen (Sudjana, 2012). Inkuiri terbimbing merupakan proses pembelajaran dimana dosen menyediakan unsur-unsur asas dan kemudian meminta mahasiswa untuk membuat generalisasi (Sudjana, 2012). Lebih lanjut menyatakan bahwa ingkuiri merupakan metode yang mengarahkan mahasiswa untuk menemukan sendiri konsep-konsep melalui percobaan. Sedangkan menurut (Hernawan et al., 
2017) bahwa metode inguiri ini dosen berperan untuk membimbing mahasiswa sampai menemukan konsep yang tepat.

Inkuiri terbimbing yang dimaksud dalam penelitian ini adalah dosen menampilkan berbagai praktek mengenai keterampailan mengajar dan mengarahkan mahasiswa untuk menemukan sendiri konsep mengajara yang menarik dan sesuai dengan materi sehingga mereka dapat mempraktekan berbagai keterampilan mengajar dalam proses pembelajaran. Keterampilan dasar mengajar merupakan sejumlah keahlian yang dimiliki oleh guru untuk memenuhi tugas mengajar yang dilaksanakan secara profesional (Sudjana, 2012). Keterampilan mengajar menurut beberapa ahli dalam hasil penelitian (Juandi \& Sontani, 2017) adalah seperangkat kemampuan yang ada pada diri seorang guru, keterampilan mengajar merupakan tindakan untuk memfasilitasi pembelajaran murid, keterampilan mengajar untuk mencapai tujuan pembelajaran. Keterampilan mengajar merupakan komptensi pedagogik yang cukup kompleks karena merupakan integrasi dari berbagai kompetensi guru secara utuh dan menyeluruh.

\section{Metode}

Penelitian ini merupakan penelitian deskriptif yang bertujuan ingin mendeskripsikan kemampuan mahasiswa dalam menerapkan keterampilan dasar mengajar. Instrumen yang digunakan untuk mengumpulkan data dengan menggunakan lembar pengamatan. Subjek penelitian ini adalah mahasiswa semester VI yang sedang mengampu Mata kuliah Praktek Pengalaman Lapangan (PPL I) pada jurusan PGSD STKIP Taman Siswa Bima. Analisis data menggunakan rumus persentase. Adapun kriteria yang digunakan dapat dilihat pada table 1.

Tabel 1. Interval kategori keteampilan mengajar mahasiswa

\begin{tabular}{cc}
\hline Interval $(\%)$ & Kategori \\
\hline $86-100$ & Sangat baik \\
$71-85$ & Baik \\
$56-70$ & Cukup baik \\
$41-55$ & Kurang baik \\
$\leq 40$ & Tidak baik \\
\hline
\end{tabular}

\section{Hasil dan Pembahasan}

Nilai rata-rata kemampuan mahasiswa dalam menyusun RPP sebesar 70,7 sedangakan reinforcemen dengan rata-rata sebesar 69, kamampaun bertanya dengan rata-rata 71, rata-rata untuk kemmapuan menutup pelajaran sebesar 72,7 dan rata-rata kemampuan menutup sebesar 74. Deskripsi kemampuan mahasiswa dalam mengajar dapat dilihat pada table 2 .

Tabel 2. Deskripsi Kemampuan Mahasiswa dalam Mengajar

\begin{tabular}{lrrrr}
\hline & Minimum & Maximum & \multicolumn{2}{c}{ Mean } \\
& Statistic & Statistic & Statistic & Std. Error \\
RPP & 60.00 & 85.00 & 70.5357 & 1.24242 \\
Reinforcemen & 60.00 & 80.00 & 69.4643 & 1.36905 \\
Question & 60.00 & 85.00 & 71.2500 & 1.35168 \\
Clousing & 60.00 & 90.00 & 72.6786 & 1.34818 \\
Opening & 65.00 & 90.00 & 74.4643 & 1.29456 \\
\hline
\end{tabular}

Dari hasil analisis deskriptif pada table 3, diperoleh kategori mahasiswa dalam menguasai keterampilan dasar mengajar. Keterampilan mahasiswa dalm membuka pelajaran berkategori baik dengan persentase 57\%, cukup baik 36\% dan baik 7\%. Untuk kemmapuan menyusun RPP berkategori baik dengan persentase 21,4\%, kategori cukup baik 78,6\%. Untuk kemampuan menutup pelajaran dengan kategori baik sebesar 53,5\%, sangat baik 3,5\%, kategori cukup baik 10,7\%. Kemampuan bertanya dengan kategori baik 50\%, cukup baik 50\% dan reinforcemen berkategori baik dengan persentase 39\%, cukup baik dengan persentase $61 \%$.

Siswa dalam proses pembelajaran memerlukan guru yang professional dan berkompeten dalam mengapliksikan berbagai keterampilan dasar mengajar agar pembelajaran menarik bagi siswa. Dari hasil 
penelitian menunjukna bahwa mahasiswa calon guru memiliki kemampuan menyusun RPP berkategori baik dengan persentase $21,4 \%$, kategori cukup baik 78,6\%. Untuk kemampuan menutup pelajaran dengan kategori baik sebesar 53,5\%, sangat baik 3,5\%, kategori cukup baik 10,7\%. Kemampuan bertanya dengan kategori baik $50 \%$, cukup baik $50 \%$ dan reinforcemen berkategori baik dengan persentase $39 \%$, cukup baik dengan persentase 61\%. Dari hasil ini menunjukan bahwa mahasiswa memeiliki kemampuan rata-rata berada pada kategori baik dan cukup baik. Hasil yang diperoleh ini merupakan hasil dari penerapan metode ingkuiri terbimbing.

Tabel 3. Pencapaian Generic Skills Teaching

\begin{tabular}{ccccc}
\hline $\begin{array}{c}\text { Pencapaian Generic Skills } \\
\text { Teaching }\end{array}$ & Interval (\%) & Frekuensi & Persentase & Kategori \\
\hline \multirow{4}{*}{ Opening } & $86-100$ & 2 & $7 \%$ & Sangat baik \\
& $71-85$ & 16 & $57 \%$ & Baik \\
& $56-70$ & 10 & $36 \%$ & Cukup baik \\
& $41-55$ & 0 & $0 \%$ & Kurang baik \\
& $\leq 40$ & 0 & $0 \%$ & Tidak baik \\
RPP & $86-100$ & 0 & $0 \%$ & Sangat baik \\
& $71-85$ & 6 & $21,4 \%$ & Baik \\
& $56-70$ & 22 & $78,6 \%$ & Cukup baik \\
& $41-55$ & 0 & $0 \%$ & Kurang baik \\
& $\leq 40$ & 0 & $0 \%$ & Tidak baik \\
Clousing & $86-100$ & 1 & $3,5 \%$ & Sangat baik \\
& $71-85$ & 15 & $53,5 \%$ & Baik \\
& $56-70$ & 3 & $10,7 \%$ & Cukup baik \\
& $41-55$ & 0 & $0 \%$ & Kurang baik \\
& $\leq 40$ & 0 & $0 \%$ & Tidak baik \\
& $86-100$ & 0 & $0 \%$ & Sangat baik \\
& $71-85$ & 14 & $50 \%$ & Baik \\
& $56-70$ & 14 & $50 \%$ & Cukup baik \\
Ruestion & $41-55$ & 0 & $0 \%$ & Kurang baik \\
& $\leq 40$ & 0 & $0 \%$ & Tidak baik \\
& $86-100$ & 0 & $0 \%$ & Sangat baik \\
& $71-85$ & 11 & $39 \%$ & Baik \\
& $56-70$ & 17 & $61 \%$ & Cukup baik \\
& $41-55$ & 0 & $0 \%$ & Kurang baik \\
& $\leq 40$ & 0 & $0 \%$ & Tidak baik \\
\hline
\end{tabular}

Keterampilan dasar mengajar mahasiswa diasah melalui kegiatan pembelajaran inkuiri terbimbing yang di dalamnya terdapat tahapan-tahapan yaitu orientasi, diamana pada tahap ini dosen mengajukan permasalahan untuk dipecahkan oleh mahasiswa, tahap ke dua adalah mahasiswa merumuskan hipotesis dan mengumpulkan data, menguji hipotesis dan membuat kesimpulan (Sudjana, 2012).Pada tahap orientasi mahasiswa diajak untuk mengenali masalah melalui video yang berkaitan dengan mengajar guru dan selanjutnya harus dipecahkan dalam tahapan inkuiri. Setelah itu mahasiswa dilatih untuk mengajukan atau merumuskan masalah berdasarkan video yang tampilkan. Berdasarkan permasalahan yang telah diajukan, mahasiswa diajak melanjutkan ke tahapan selanjutnya yaitu membuat dugaan/hipotesis. Untuk menjawab hipotesis yang artinya mahasiswa diberi kesempatan untuk memprediksi penyebab masalah yang muncul di awal kegiatan. Tahapan selanjutnya dalam inkuiri adalah pengumpulan data dan pengujian hipotesis. Dengan melalui ingkuiri ini mahasiswa dapat menganalisis kegiatan mengajar guru

Hal ini sejalan dengan hasil penelitian (Surakarta et al., 2012) bahwa pembelajaran inkuiri terbimbing sangat sesuai untuk mengembangkan keterampilan mahasiswa, karena sintak atau tahap pembelajarannya dikembangkan dengan metode ilmiah yang dapat melatihkan keterampilan mahasiswa.

Guru merupakan salah satu faktor penting dalam proses pembelajaran, dimana guru memiliki peran utama dalam proses pembelajaran yang berlangsung di kelas. Dalam mengajar guru tentu harus memiliki komptensi, yang terdiri dari komptensi pedagogi, kompetensi profesional, kompetensi kepribadian, dan 
kompetensi social (Sudjana, 2012). Komptensi pedagogic Salah satu unsurnya adalah keterampilan mengajar guru. Keterampilan mengajar merupakan seperangkat kompetensi dalam tindakan untuk memfasilitasi pembelajan siswa yang bertujuan untuk mencapai tujuan pembelajaran. Tercapainya tujuan pembelajaran diindikasikan oleh prestasi yang diperoleh oleh siswa.

Keterampilan mengajar memiliki kaitan erat dengan prestasi belajar. (Sudjana, 2012) berpendapat bahwa proses dan prestasi belajar siswa sangat bergantung pada penguasan mata pelajaran oleh guru dan keterampilan mengajarnya, lebih lanjut menyampaikan bahwa Salah satu faktor yang memilki pengaruh kuat terhadap kualititas belajar atau prestasi belajar siswa adalah kualitas keterampilan guru. Keterampialn seorang guru memiliki pengaruh signifikan terhadap prestasi belajar siswa (Sudjana, 2012).

Kegiatan mengelolaan kelas perlu menciptakan suasana yang menggembirakan atau menyenangkan bagi semua yang ada di dalam kelas tersebut, dengan menjalin keakraban antara semua, maka pengajar dapat mengarahkan siswa dengan lebih mudah agar terdorong dan termotivasi untuk belajar. Pembelajaran menyenangkan adalah pembelajaran dimana interaksi antara pengajar dan siswa, lingkungan fisik, dan suasana memberikan peluang terciptanya kondisi yang kondusif untuk belajar. Suasana pembelajaran yang menyenangkan bagi siswa tidak akan membuat siswa merasa bosan dan tidak akan merasa takut dalam melibatkan diri dalam proses pembelajaran. Dalam proses pembelajaran guru harus menciptakan susana kondusif dan siswa dituntut aktif untuk mengembangkan ide kreatifitasnya dalam bertanya, mempertanyakan masalah-masalah yang muncul dalam pembelajaran, serta mengemukakan gagasannya. Dengan demikian dalam pembelajaran guru tidak mendominasi aktivitas belajar-mengajar, tetapi siswa yang lebih banyak melakukan aktivitas belajar. Artinya dalam setiap kali tatap muka, guru harus menggunakan metode dan model secara bervariatif.

Aktivitas yang dilaksanakan guru untuk memenuhi komponen dalam membuka pelajaran dapat membantu siswa mendapatkan bimbingan untuk memiliki kesiapan dalam belajar terutama kesiapan mental siswa. Sementara itu, pelaksanaan keterampilan menutup pelajaran dapat digunakan untuk melihat hasil atau capaian pembelajaran yang telah dilaksanakan. Menurut Ojukwu dalam artikelnya (Juandi \& Sontani, 2017) kesimpulan diperlukan di setiap akhir pembelajaran untuk memberikan penguatan pada hal-hal penting yang terdapat dalam pembelajaran agar lebih bermakna bagi siswa. Sehingga dapat dinyatakan bahwa meninjau kembali dengan menyampaikan kesimpulan perlu dilaksanakan agar berdampak positif bagi siswa.

\section{Simpulan}

Dari hasil penelitian dapat di ketahui bahwa penerapan metode ingkuri terbimbing dapat mengembangkah keterampilan dasar mengajar mahasiswa. Nilai rata-rata kemampuan mahasiswa dalam menyusun RPP sebesar 70,7 sedangakan reinforcemen dengan rata-rata sebesar 69, kamampaun bertanya dengan rata-rata 71 , rata-rata untuk kemmapuan menutup pelajaran sebesar 72,7 dan rata-rata kemampuan menutup sebesar 74. Kemampuan menyusun RPP berkategori baik dengan persentase 21,4\%, kategori cukup baik 78,6\%. Untuk kemampuan menutup pelajaran dengan kategori baik sebesar 53,5\%, sangat baik 3,5\%, kategori cukup baik $10,7 \%$. Kemampuan bertanya dengan kategori baik 50\%, cukup baik $50 \%$ dan reinforcemen berkategori baik dengan persentase $39 \%$, cukup baik dengan persentase $61 \%$.

\section{Ucapan Terima Kasih}

Ucapan terimakasih disampaikan kepada LLDIKTI wilayah VIII yang mendanai penelitian ini pada skim Penelitia Dosen Pemula (PDP) tahun anggaran 2020. Ucapan terimkasih juga disampaikan kepada Ketua STKIP Taman Siswa Bima, Dewan Pembina dan Yayasan beserta LPPM, Prodi beserta teman-teman dosen lingkup STKIP Taman Siswa Bima

\section{Daftar Pustaka}

Abu, S. N. (2014). Pembinaan Guru Oleh Kepala Sekolah Dalam. 2, 704-712.

Hernawan, I., Studi, P., Ilmu, P., \& Alam, P. (2017). Implementasi Pembelajaran Inkuiri Terbimbing Berbasis Information Technologi ( IT ) Untuk Meningkatkan Kreativitas Dan Hasil Belajar Siswa Pada Materi Pernapasan Manusia Indra Hernawan. 2(1), 36-42.

Juandi, A., \& Sontani, U. T. (2017). Keterampilan dan kreativitas mengajar guru sebagai determinan terhadap prestasi belajar siswa. 
2(2), 242-250.

Khakiim, U., Degeng, I. N. S., \& Widiati, U. (2016). Pelaksanaan Membuka Dan Menutup Pelajaran Oleh Guru Kelas 1 Sekolah Dasar. 2007, 1730-1734.

Mariamah. (n.d.). KEEFEKTIFAN PEMBELAJARAN KOOPERATIF TIPE STUDENT TEAMS ACHIEVEMENT DIVISION ( STAD ) DAN NUMBER HEAD TOGETHER ( NHT ) DITINJAU PADA ASPEK PRESTASI DAN MOTIVASI BELAJAR MATEMATIKA SISWA SMA NEGERI 1 PALIBELO BIMA Mariamah Dosen Program Studi Pendidikan Mat. 2(1), 122-134.

Muhamad Ajwar, Mariamah, Hardiansyah, \& Syahriani Yulianci. (2019). Penggunaan Open Ended untuk Meningkatkan Kreativitas Belajar Mahasiswa pada Mata Kuliah Konsep Dasar IPA. Jurnal Pendidikan Mipa, 9(1), 10-14. https://doi.org/10.37630/jpm.v9i1.154

Sudjana, N. (2012). Teori Belajar dan Pembelajaran. Rineka Cipta. https://doi.org/10.1007/s10984-016-9215-8

Surakarta, S. M. A. N., Of, A., \& Negeri, S. M. A. (2012). PENGARUH MODEL PEMBELAJARAN INKUIRI TERBIMBING TERHADAP KETERAMPILAN PROSES SAINS DITINJAU DARI KEMAMPUAN AKADEMIK SISWA SCIENCE PROCESS SKILLS VIEWED FROM STUDENT' S ACADEMIC. 4, 33-43.

Widodo, A., Sumarno, U., \& Nurjhani, M. (2017). “Lesson DALAM PERANAN “ LESSON STUDY ” PENINGKATAN KEMAMPUAN MENGAJAR. 